\title{
Deducing the Bioactive Face of Hydantoin Anticonvulsant Drugs Using NMR Spectroscopy
}

\author{
Kathryn E Tiedje, Donald F Weaver
}

\begin{abstract}
Background: The general purpose of this study was to deduce the geometry of the bioactive face (pharmacophore) for the hydantoin class of anticonvulsants. Methods: Six hydantoin analogs, selected as probes of hydantoin structure, were synthesized. Nuclear magnetic resonance spectroscopy and molecular modelling calculations were used to determine the geometric relationship between the aromatic group and the amide group in the hydantoin pharmacophore. Results: In accord with both theoretical and experimental results, the biologically inactive hydantoin analogs containing a benzyl substituent existed in a folded conformation with the benzene flopped over the hydantoin ring. Conversely the biologically active hydantoins had a phenyl ring extended away from the hydantoin ring. Conclusions: The bioactive face for hydantoins consists of a $\mathrm{N}(\mathrm{H})-\mathrm{C}(=\mathrm{O})-\mathrm{X}$-phenyl molecular fragment, where $\mathrm{X}$ is a carbon or nitrogen atom and where the distance between the centre of the amide bond and the centroid of the phenyl ring is $4.3 \AA$.
\end{abstract}

RÉSUMÉ: Utilisation de la spectroscopie par résonance magnétique nucléaire pour déduire la face bioactive des médicaments anticonvulsivants de la classe de l'hydantoïne. Contexte : Le but de cette étude était de déduire quelle est la géométrie de la face bioactive (pharmacophore) des anticonvulsivants de la classe de l'hydantoïne. Méthodes : Six analogues de l'hydantoïne choisis comme sondes pour examiner la structure de l'hydantoïne ont été synthétisés. La spectroscopie par résonance magnétique nucléaire (RMN) et des calculs par modélisation moléculaire ont été utilisés pour déterminer la relation géométrique entre le groupe aromatique et le groupe amide dans le pharmacophore de l'hydantoïne. Résultats : Les analogues de l'hydantoïne qui contiennent un substituant benzyle sont inactifs au point de vue biologique et possèdent une conformation repliée, le benzène étant rabattu sur l'anneau hydantoïne, ce qui concorde avec les données théoriques et expérimentales. À l'opposé, les analogues bioactifs de l'hydantoïne ont un anneau phényle qui s'écarte de l'anneau hydantoïne. Conclusions : La face bioactive des analogues de l'hydantoïne consiste en un fragment moléculaire $\mathrm{N}(\mathrm{H})-\mathrm{C}(=0)$-X-phényle où le $\mathrm{X}$ est un atome de carbone ou d'azote et où la distance entre le centre du pont amide et le centroïde de l'anneau phényle est de $4,3 \approx$.

Can. J. Neurol. Sci. 2008; 35: 232-236

All drugs are molecules, but not all molecules are drugs. Specific dimensions and physical properties are required for a molecule to become a successful drug. Anticonvulsant drugs are molecules whose geometric dimensions permit an ability to interact with a receptor and to elicit a desired seizure suppressing response. The entire anticonvulsant molecule is not required for this bioactivity; the fragment of the drug molecule that actually interfaces and docks with the receptor is termed the "bioactive face" (or pharmacophore). Thus, a bioactive face possesses one or more clusters of atoms positioned in three-dimensional space on a structural framework, holding them in a defined geometrical array that enables the molecule to bind specifically to a targeted biological macromolecular receptor. In modern drug design, an understanding of the geometry of the bioactive face is crucial for

From the Departments of Medicine (DFW) and Chemistry (KET, DFW), School of Biomedical Engineering (DFW), Dalhousie University, Halifax, Nova Scotia, Canada. Received April 10, 2007. Final Revisions Submitted December 21, 2007. Reprint requests to: Donald F. Weaver, Departments of Medicine and Chemistry, Chemistry Building, Dalhousie University, Halifax, Nova Scotia, B3H 4J3, Canada. 
drug discovery and design. Although therapeutic molecules such as phenytoin (5,5-diphenylhydanotin) have long been the mainstay of anticonvulsant therapy, the hydantoin bioactive face remains incompletely elucidated. ${ }^{1}$ This is a potential stumbling block to the rational development of $\mathrm{Na}+$ channel-active agents for seizure suppression. ${ }^{2}$

Previous work from our laboratory and others has clearly shown that the bioactive face of hydantoin contains of an amide group ( $\mathrm{R}^{\prime}-\mathrm{N}(\mathrm{H})-\mathrm{C}(=\mathrm{O})-\mathrm{R}$ ") and a lipophilic (preferably aromatic [e.g. phenyl]) group. ${ }^{3,4}$ Although this work has qualitatively identified the molecular building blocks of the bioactive face, it has not quantitatively deduced the precise geometric relationship between the lipophilic group and the amide group.

The main purpose of this study was to synthesize selected hydantoin analogues as structural probes and then to use nuclear magnetic resonance (NMR) spectroscopy and molecular imaging/modelling calculations to determine the precise geometric relationship between the lipophilic group and the amide group; this will then be correlated with bioactivity. This study will afford an improved understanding of the geometry of the bioactive face of phenytoin and the overall hydantoin class.

\section{Methods And Materials}

\section{Selection and Synthesis of Hydantoin Analogues}

The phenyl ring was selected as a structural probe for the lipophilic group. Specific hydantoins were chosen to evaluate the influence of aromatic/amide geometry on anticonvulsant bioactivity (shown in Figure 1). To explore molecular diversity space, these compounds all contain an aromatic group at either the $\mathrm{N}^{3}$ or $\mathrm{C}^{5}$ position.

Appendix A presents the syntheses of compounds 1, 2, 3, 4, 5 and 6 , which were prepared according to similar literature

\begin{tabular}{|l|l|l|l|l|l|}
\hline & Compound name & $\mathrm{R}_{\mathrm{I}}$ & $\mathrm{R}_{2}$ & $\mathrm{R}_{3}$ & $\mathrm{R}_{4}$ \\
\hline $\mathbf{1}$ & (S)-5-benzylhydantoin & $\mathrm{H}$ & $\mathrm{H}$ & $\mathrm{Bn}$ & $\mathrm{H}$ \\
\hline $\mathbf{2}$ & (S)-5-phenylhydantoin & $\mathrm{H}$ & $\mathrm{H}$ & $\mathrm{Ph}$ & $\mathrm{H}$ \\
\hline $\mathbf{3}$ & 5,5-diphenylhydantoin & $\mathrm{H}$ & $\mathrm{H}$ & $\mathrm{Ph}$ & $\mathrm{Ph}$ \\
\hline $\mathbf{4}$ & 3-benzylhydantoin & $\mathrm{H}$ & $\mathrm{Bn}$ & $\mathrm{H}$ & $\mathrm{H}$ \\
\hline $\mathbf{5}$ & 3-phenylhydantoin & $\mathrm{H}$ & $\mathrm{Ph}$ & $\mathrm{H}$ & $\mathrm{H}$ \\
\hline $\mathbf{6}$ & (R)-3,5-diphenylhydantoin & $\mathrm{H}$ & $\mathrm{Ph}$ & $\mathrm{Ph}$ & $\mathrm{H}$ \\
\hline
\end{tabular}

Figure 1: General structure of the hydantoin derivatives synthesized, where the Rn group are as follows: $\mathrm{Bn}=$ benzyl $\left(-\mathrm{CH}_{2} \mathrm{C}_{6} \mathrm{H}_{5}\right) ; \mathrm{Ph}=$ phenyl $\left(-\mathrm{C}_{6} \mathrm{H}_{5}\right) ; \mathrm{H}=$ hydrogen. preparations. ${ }^{5-11} 1 \mathrm{H}$ and $13 \mathrm{C}$ nuclear magnetic resonance spectra were recorded using a Bruker AVANCE $500 \mathrm{MHz}$ spectrometer. Chemical shifts $(\delta)$ are reported as parts per million downfield from the tetramethylsilane (TMS) and are calibrated using the solvent peaks or when possible, the TMS peak present some of the deuterated solvents. Coupling constants $(\mathrm{J})$ are reported in $\mathrm{Hz}$.

\section{Biological Testing of Hydantoin Analogues}

The six hydantoin analogues were each administered to five adult male Sprague Dawley rats at $20 \mathrm{mg} / \mathrm{kg}$ intraperitoneally; 15 minutes later pilocarpine $(300 \mathrm{mg} / \mathrm{kg}$ ) was administered intraperitoneally. ${ }^{12-14}$ The number of rats showing generalized convulsions was determined. These results are in agreement with biological activities as determined in a maximal electroshock assay (obtained from different laboratories using varying techniques) taken from literature sources. ${ }^{15}$

\section{Nuclear Magnetic Resonance Spectroscopy Structural Analyses of Hydantoin Analogues}

Molecular shape analysis (i.e. conformational analysis) of the six hydantoins was performed using one dimensional nuclearOverhauser effect (nOe) spectroscopy (1D-NOESY) experiments. The nOe is a through-space effect and can be used to determine if a specific ${ }^{1} \mathrm{H}$ proton is positioned near another ${ }^{1} \mathrm{H}$ proton. This NMR experiment can be a particularly powerful tool for determining the spatial relationship of protons in a molecule. All NMR experiments were performed on a Bruker AVANCE 500 $\mathrm{MHz}$ spectrometer, in deuterated DMSO- $\mathrm{d}_{6}$ at $25^{\circ} \mathrm{C}$. The $\mathrm{N}^{1}$ and $\mathrm{N}^{3}$ protons at $7.92 \mathrm{ppm}$ and $10.43 \mathrm{ppm}$ for compound 1 and the $\mathrm{N}^{1}$ and $\mathrm{N}^{3}$ protons at $6.80 \mathrm{ppm}$ and $12.82 \mathrm{ppm}$ for compound 2 were chosen and excited to study the nOe effects for each analogue.

\section{Molecular Modelling Calculations of Hydantoin Analogues}

Theoretical molecular modelling calculations were used to determine the optimal geometry of the hydantoin analogues. This was achieved by using a "mechanics" method that permits the geometry of a hydantoin molecule to be expressed as a function of energy; by minimizing this energy function, one can ascertain the optimal geometry of the hydantoin molecule. In this study, molecular mechanics was the mechanics method employed. Molecular mechanics refers to a heavily parameterized calculational method that leads to accurate geometries and accurate relative energies for different conformations of molecules. Molecular mechanics conceptualises a molecule as a collection of particles held together by elastic or harmonic forces, which can be defined individually in terms of potential energy functions. The sum of these various potential energy equations comprises a multidimensional energy function termed the force field, which describes the restoring forces acting on a molecule when the minimal potential energy is perturbed. Thus, molecular mechanics uses an empirically derived set of simple classical mechanical equations, and is in principle well suited to provide accurate a priori structures and energies for varying conformations of hydantoin analogues.

The energy minimization molecular modelling calculations were performed using the MM2 force field implemented in 
Table 1: The calculated mean distances and standard deviations between the centre of the amide bond and the centroid of the aromatic ring and the anticonvulsant activities, where the values indicate the number of animals tested compared to the number of animals that exhibited seizure protection

\begin{tabular}{|c|c|c|c|c|}
\hline \multirow[t]{2}{*}{$\#$} & \multirow[t]{2}{*}{ Compound Name } & \multirow[t]{2}{*}{ Calculated Distance $(\AA)$} & \multicolumn{2}{|c|}{ Biological Testing } \\
\hline & & & $\begin{array}{c}\text { Animals } \\
\text { Tested }\end{array}$ & $\begin{array}{l}\text { Animals } \\
\text { Protected }\end{array}$ \\
\hline 1 & (S)-5-benzylhydantoin & $\begin{array}{l}\mathrm{N}^{1} 3.8 \pm 0.1 \\
\mathrm{~N}^{3} 4.0 \pm 0.1\end{array}$ & 5 & 0 \\
\hline 2 & (S)-5-phenylhydantoin & $\begin{array}{l}\mathrm{N}^{1} 4.2 \pm 0.1 \\
\mathrm{~N}^{3} 4.3 \pm 0.1\end{array}$ & 5 & 3 \\
\hline 3 & 5,5-diphenylhydantoin & $\begin{array}{l}\mathrm{N}^{1} 4.2 \pm 0.1 / 4.1 \pm 0.1 \\
\mathrm{~N}^{3} 4.3 \pm 0.1 / 4.3 \pm 0.1\end{array}$ & 5 & 5 \\
\hline 4 & 3-benzylhydantoin & $\begin{array}{l}\mathrm{N}^{1} 5.5 \pm 0.1 \\
\mathrm{~N}^{3} 3.9 \pm 0.1\end{array}$ & 5 & 0 \\
\hline 5 & 3-phenylhydantoin & $\begin{array}{l}\mathrm{N}^{1} 4.4 \pm 0.1 \\
\mathrm{~N}^{3} 3.5 \pm 0.1\end{array}$ & 5 & 3 \\
\hline 6 & (S)-3,5-diphenylhydantoin & $\begin{array}{l}\mathrm{N}^{1} 4.7 \pm 0.1 / 4.2 \pm 0.1 \\
\mathrm{~N}^{3} 3.5 \pm 0.1 / 4.2 \pm 0.1\end{array}$ & 5 & 0 \\
\hline
\end{tabular}

Chem 3D Ultra $8.0^{16}$ where an extended geometry was used as the starting conformation for each molecule.

\section{RESULTS}

Compounds 1 and 2 are both substituted at the $C^{5}$ position but show varying ability to prevent seizure activity with only a one carbon chain length difference at the $\mathrm{C}^{5}$ position (benzyl vs. phenyl); compounds 4 and 5 are both substituted at the $\mathrm{C}^{3}$ position but show varying ability to prevent seizure activity with only a one carbon chain length difference at the $\mathrm{C}^{3}$ position (benzyl vs. phenyl).

The computationally optimized geometries of (S)-5benzylhydantoin and (S)-5-phenylhydantoin show clear differences in the calculated distance between the $\mathrm{N}^{3}$ amide bond and the aromatic ring (Table 1). The 1D-NOESY studies of (S)5-benzylhydantoin (1) showed an nOe effect between the protons of the $\mathrm{N}^{1} / \mathrm{N}^{3}$ amide bond (7.92 ppm/ $10.43 \mathrm{ppm}$ ) and the protons of the aromatic ring (7.18 ppm-7.29 ppm). The nOe effects observed in (S)-5-phenylhydantoin (2) between the $\mathrm{N}^{1}$ amide bond proton $(6.80 \mathrm{ppm})$ and the aromatic protons (7.34 ppm-7.40 ppm) was weaker in comparison (no nOe enhancement was seen between the $\mathrm{N}^{3}$ amide bond proton (12.82 ppm) and the aromatic protons (7.34 ppm-7.40 ppm)) (see Figure 2). (The 1D-NOESY spectra are available at http://chemistry.dal.ca/Faculty/ Professors/Weaver \%2C_Don.php).

\section{Discussion}

The correlation between structure and anticonvulsant activity is apparent from the biological results in the Table. The 1DNOSEY data provide important conformational information that supports the molecular modelling results. Observation of the 1D-
NOESY results for (S)-5-benzylhydantoin shows a through space interaction between the $\mathrm{N}^{1}$ proton at $7.92 \mathrm{ppm}$ and the protons of the aromatic ring at 7.18-7.29 ppm. The nOe data help to support the hypothesis of a folded conformation for the (S)-5benzylhydantoin (1), with the benzene ring being flopped over the hydantoin ring. This confirms a spatial relationship between the $\mathrm{N}^{1}$ amide and the aromatic moiety of the benzyl group. The nOe for (S)-5-phenylhydantoin (2) support the hypothesis that the aromatic ring is in an extended position relative to the hydantoin ring, and is not in a folded conformation as in the 5benzyl analogue. Accordingly the 1D-NOSEY results show limited or no nOe enhancement for (S)-5-phenylhydantoin (2) between the $\mathrm{N}^{1 /} \mathrm{N}^{3}$ amide bond protons (6.80 ppm/ $\left.12.82 \mathrm{ppm}\right)$ and the aromatic protons (7.34 ppm-7.40 ppm), which is compatible with computational and biological results.

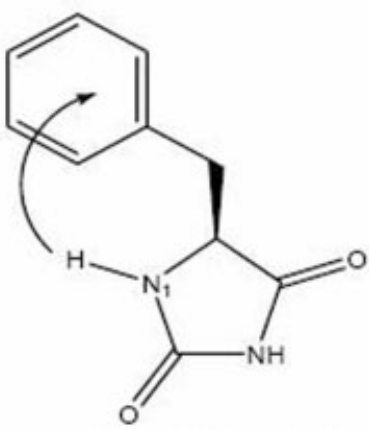

(S)-5-benzylhydantoin (1)

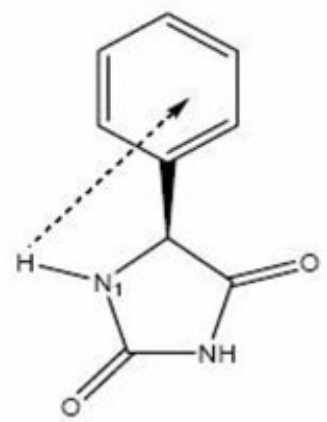

(S)-5-phenylhydantoin (2)
Figure 2: Relevant nOes observed for the (S)-5benzylhydantoin and (S)5-phenylhydantoin. Solid and dotted lines represent strong and week nOes respectively.

Computational studies support these experimental results. For (S)-5-benzylhydantoin(1), an intramolecular interaction between the aromatic ring and the hydrogen of the $\mathrm{N}^{1}$ amide bond creates a folded geometry which is controlled by a nonbonded interaction between the $\pi$-electrons of the aromatic ring and the dipole of the amide bond. ${ }^{17-19}$ The (S)-5-phenylhydantoin (2) is an active compound and assumes a conformation with the aromatic ring extended away from the hydantoin ring and the $\mathrm{N}^{3}$ amide bond. For the $\mathrm{C}^{5}$ substituted bioactive hydantoin analogues, the $\mathrm{N}^{3}-\mathrm{C}^{4}\left(=\mathrm{O}^{7}\right)$ amide-to-phenyl distance is $4.3 \pm 0.1 \AA$.

3-Phenylhydantoin (5) is a biologically active compound with a calculated amide bond-to-phenyl ring distance of $4.4 \pm 0.1 \AA$. This distance is similar to the bioactive $C^{5}$ substituted compounds. The inactivity of 3,5-diphenylhydantoin (6) 
probably arises from the steric bulk of having a phenyl ring attached to the amide moiety.

In conclusion, the bioactive face for hydantoins consists of a $\mathrm{R}^{\prime}-\mathrm{N}(\mathrm{H})-\mathrm{C}(=\mathrm{O})-\mathrm{X}$-phenyl molecular fragment, where $\mathrm{X}$ is a carbon or nitrogen atom and where the distance between the centre of the amide bond and the centroid of the phenyl ring is $4.3 \AA$. For compounds 2 and 3 , the bioactive face is the $\mathrm{N}^{3}$ $\mathrm{C}^{4}\left(=\mathrm{O}^{7}\right)-\mathrm{C}^{5}-\mathrm{R}^{4}$; for compound 5 an equivalent bioactive face is $\mathrm{N}^{1}-\mathrm{C}^{2}\left(=\mathrm{O}^{6}\right)-\mathrm{N}^{3}-\mathrm{R}^{2}$. This extended geometry of the amide bond/aromatic ring pharmacophore aids in binding to the fastinactivated state of the neuronal sodium channel, thereby inhibiting seizure activity.

\section{ACKNOWLEDGEMENTS}

KET acknowledges salary support from the Nova Scotia Health Research Foundation and Epilepsy Canada. DFW acknowledges salary support from a Canada Research Chair, Tier 1 , in Neuroscience. Molecular modelling software was acquired with the support of a grant from the Dalhousie Medical Research Foundation. The authors have no conflicts of interest to declare.

\section{REFERENCES}

1. Merritt HH. Sodium diphenyl hydantoinate in the treatment of convulsive disorders. Arch Neurol Psychiat. 1938; 39: 1003-8.

2. Dichter MA. Mechanisms of action of new antiepileptic drugs. Adv Neurol. 1998; 76: 1-9.

3. Codding PW, Lee TA, Richardson JF. Cyheptamide and 3-hydroxy3-phenacyloxindole: structural similarity to diphenylhydantoin as the basis for anticonvulsant activity. J Med Chem. 1984; 27 : 649-52.

4. Weaver DF. Applications of molecular physics biotechnology to the rational design of an improved phenytoin analogue. Seizure. 1993; 1: 223-46.

5. Boyd WJ. Isolation of amino acids in the form of the corresponding carbamido acids and hydantoins. I. The derivatives of the monoaminomonocarboxylic acids. Biochem J. 1933; 26: 1838-48.

6. Frerichs G, Hollmann M, Beckurts H. Beiträge zur Kenntnis der Arylhydantoine. Arch Pharm. 1905; 243: 684-710.

7. Finkbeiner HL, Stiles M. Chelation as a driving force in organic reactions. IV. Synthesis of a-nitro acids by control of the carboxylation-decarboxylation equilibrium. J Am Chem Soc. 1963; 85: 616-72.

8. Finkbeiner HL. The carboxylation of hydantoins. J Org Chem. 1965; 30: 3414-19.

9. Aschan O. Ueber die Einwirkung von Phenylsenföl auf Amidofettsäuren. Chem Ber. 1883; 16: 1544-5.

10. Fischer E. Spaltung racemischer Aminosäuren in die optisch activen Componenten. III. Chem Ber. 1900; 33: 2370-82.

11. Dunnavant WR, James FL. Molecular rearrangements. I. The basecatalyzed condensation of benzil with urea. J Am Chem Soc. 1956; 78: 2740-3.

12. Lyon AP, Wainman D, Marone S, Weaver DF. Implementing a bioassay to screen molecules for antiepileptogenic activity: chronic pilocarpine versus subdudral haematoma models. Seizure. 2004; 13: 82-6.

13. Lyon AP, Wainman D, Marone S, Weaver DF. A spontaneous recurrent seizure bioassay for anti-epileptogenic molecules. Can J Neurol Sci. 2005; 32: 97-102.

14. Turski L, Ikonomidou C, Turski WA, Bortolotto ZA, Cavalheiro EA. Review: cholinergic mechanisms and epileptogenesis. The seizures induced by pilocarpine: a novel experimental model of intractable epilepsy. Synapse. 1989; 3: 154-71.

15. Close WJ, Doub L, Spielman MA. Anticonvulsant drugs. J Med Chem. 1961; 5: 1-78.

16. Chem 3D Ultra. 2004. Version 8.0.
17. Fujiwara H, Bose AK, Manhas MS, van der Veen JM. Non-bonded aromatic-amide attraction in 5-benzyl-3-arylhydantoins. J Chem Soc Perkin Trans. II. 1979; 653-8.

18. Fujiwara H, van der Veen JM. An X-ray study of the aromatic ringdipole interaction in hydantoin crystals. J Chem Soc Perkin Trans. II. 1979; 659-63.

19. Robinson R, Jencks WP. The effect of concentrated salt solutions on the activity coefficient of acetyltetraglycine ethyl ester. J Am Chem Soc. 1965; 87: 2470-2.

\section{Appendix: Syntheses of Hydantoin Analogues}

\section{(S)-5-Benzylhydantoin (1)}

A solution of L-phenylalanine $(8.3 \mathrm{~g}, 0.05 \mathrm{~mol})$ and potassium cyanate $(4.0 \mathrm{~g}, 0.05 \mathrm{~mol})$ in water $(20 \mathrm{~mL})$ were combined and heated at reflux for $1 \mathrm{~h}$. After one hour, conc. $\mathrm{HCl}(7.5 \mathrm{~mL})$ was added, and the reaction mixture was heated at reflux for an additional 10 minutes. The solution was then cooled in an ice bath, which promoted crystal formation. The product was collected by suction filtration and recrystallized using an ethanol and water (95:5) mixture. (Crystalline solid (8.21g, 85\%); mp 189-191 ${ }^{\circ} \mathrm{C}$ (lit. mp: $189-190{ }^{\circ} \mathrm{C}$ [8]); ${ }^{1} \mathrm{H}$ NMR (DMSO-d ): 2.91 (dd, $1 \mathrm{H}, J=5.6,14.2), 2.99(\mathrm{dd}, 1 \mathrm{H}, J=4.9,14.2), 4.33(\mathrm{~m}, 1 \mathrm{H}), 7.18-7.29$ $(\mathrm{m}, 5 \mathrm{H}), 7.92(\mathrm{~d}, 1 \mathrm{H}, J=9.8), 10.4(\mathrm{~s}, 1 \mathrm{H}) ;{ }^{13} \mathrm{C}$ NMR (DMSO-d $\left.\mathrm{d}_{6}\right): 36.8$, 59.6, 126.8, 128.2, 129.6, 135.4, 158.5, 176.1; HRMS: $\mathrm{C}_{10} \mathrm{H}_{10} \mathrm{~N}_{2} \mathrm{O}_{2}$ calculated $190.0742 \mathrm{amu}$, found $190.0739 \mathrm{amu}$.)

\section{(S)-5-Phenylhydantoin (2)}

The synthesis was conducted in a similar manner to (S)-5benzylhydantoin (1), however, L-phenylglycine (7.5 g, $0.05 \mathrm{~mol}$ ) was used instead of L-phenylalanine. The product was recrystallized using an ethanol and water (95:5) mixture. (Crystalline solid (7.25 g, 92\%); mp 176- $177{ }^{\circ} \mathrm{C}$ (lit. mp: $\left.177-178{ }^{\circ} \mathrm{C}[8]\right) ;{ }^{1} \mathrm{H}$ NMR (DMSO-d ${ }_{6}$ ): 5.18 (d, $1 \mathrm{H}$, $J=10.1), 6.80(\mathrm{~d}, 1 \mathrm{H}, \mathrm{J}=10.1), 7.32-7.39(\mathrm{~m}, 5 \mathrm{H}), 12.82(\mathrm{~s}, 1 \mathrm{H}) ;{ }^{13} \mathrm{C}$ NMR (DMSO-d $)$ : 57.2, 127.1, 127.9, 128.5, 137.9, 159.9, 173.3; HRMS: $\mathrm{C}_{9} \mathrm{H}_{18} \mathrm{~N}_{2} \mathrm{O}_{2}$ calculated $176.0586 \mathrm{amu}$, found $176.0588 \mathrm{amu}$.)

\section{5,5-Diphenylhydantoin (3)}

A solution of benzil $(5.8 \mathrm{~mL}, 0.05 \mathrm{~mol})$ and urea $(0.1 \mathrm{~mol})$ in $95 \%$ ethanol $(20 \mathrm{~mL})$ was stirred. To this solution $6 \mathrm{M} \mathrm{NaOH}(1.2 \mathrm{~mL})$ was added and the mixture was heated at reflux for $90 \mathrm{~min}$. The solution was then cooled to room temperature and the unreacted solid was filtered off. The remaining solution was acidified with $2 \mathrm{M} \mathrm{HCl}$ until a precipitate was formed. The solid was collected by filtration and was crystallized using an ethanol and water (95:5) mixture. (Crystalline product (11.4 g, 92\%); mp 296-298 ${ }^{\circ} \mathrm{C}$ (lit. mp: $295-298{ }^{\circ} \mathrm{C}$ [11]); ${ }^{1} \mathrm{H}$ NMR $\left(\mathrm{CD}_{3} \mathrm{OD}\right)$ : 7.33-7.39 (m, 10H); ${ }^{13} \mathrm{C}$ NMR $\left(\mathrm{CD}_{3} \mathrm{OD}\right): 70.6,126.5,127.5,128.6$, 140.0, 156.9, 175.6; HRMS: $\mathrm{C}_{15} \mathrm{H}_{12} \mathrm{~N}_{2} \mathrm{O}_{2}$ calculated $252.0899 \mathrm{amu}$, found $252.0891 \mathrm{amu}$ )

\section{3-Benzylhydantoin (4)}

A solution of sodium hydroxide $(2.0 \mathrm{~g}, 0.05 \mathrm{~mol})$ was dissolved in water $(20 \mathrm{~mL})$ and hydantoin $(5.0 \mathrm{~g}, 0,05 \mathrm{~mol})$ was added, and the solution was brought to reflux for $15 \mathrm{~min}$. To this solution benzyl chloride $(5.8 \mathrm{~mL}$, $0.05 \mathrm{~mol}$ ), was added and the mixture was stirred and heated for an additional $20 \mathrm{~h}$. The reaction mixture was then poured over $40 \mathrm{~g}$ of crushed ice. The product quickly precipitated and was then filtered off and crystallized using an ethanol and water (95:5) mixture. (Crystalline product $(7.6 \mathrm{~g}, 80 \%) ; \mathrm{mp}=140-141 \infty \mathrm{C}$ (lit. $\mathrm{mp}=141 \infty \mathrm{C}$ [8]); ${ }^{1} \mathrm{H}$ NMR $\left(\mathrm{CD}_{3} \mathrm{OD}\right): 3.08(\mathrm{~s}, 2 \mathrm{H}), 4.32(\mathrm{~s}, 2 \mathrm{H}), 7.33-7.39(\mathrm{~m}, 5 \mathrm{H}) ;{ }^{13} \mathrm{C} \mathrm{NMR}$ (CD $\left.{ }_{3} \mathrm{OD}\right)$ : $35.9,57.4,126.8,127.9,129.4,132.3,156.4,174.5$; HRMS: $\mathrm{C}_{10} \mathrm{H}_{10} \mathrm{~N}_{2} \mathrm{O}_{2}$ calculated $190.0742 \mathrm{amu}$, found $190.0744 \mathrm{amu}$.)

\section{3-Phenylhydantoin (5)}

A solution of glycine $(3.8 \mathrm{~g}, 0.05 \mathrm{~mol})$ was dissolved in water $(20 \mathrm{~mL})$ containing potassium hydroxide $(3.0 \mathrm{~g}, 0.05 \mathrm{~mol})$. After the solution was stirred for $10 \mathrm{~min}$, phenylisocyanate $(6.0 \mathrm{~g}, 0.05 \mathrm{~mol})$ was added and the mixture was warmed to $65^{\circ} \mathrm{C}$ for $5 \mathrm{~h}$. The solution was then cooled and left to sit for $2 \mathrm{~h}$. The solid diphenylurea, which formed, was filtered off and the filtrate was acidified with concentrated $\mathrm{HCl}$ to precipitate the hydantoic acid. The hydantoic acid was cyclized by refluxing for $1 \mathrm{~h}$ in 
$50 \mathrm{~mL}$ of water and $50 \mathrm{~mL}$ of concentrated $\mathrm{HCl}(5 \mathrm{~mL})$. When the solution had cooled the product crystallized. It was then collected by filtration and then recrystallized using an ethanol and water (95:5) mixture. (Crystalline product $(7.4 \mathrm{~g}, 84 \%)$; $\mathrm{mp}=155-157^{\circ} \mathrm{C}$ (lit. $\mathrm{mp}=$ 154- $\left.155^{\circ} \mathrm{C}[8]\right) ;{ }^{1} \mathrm{H}$ NMR $\left(\mathrm{CD}_{3} \mathrm{OD}\right): 4.21(\mathrm{~s}, 2 \mathrm{H}), 7.31-7.45(\mathrm{~m}, 5 \mathrm{H}) ;{ }^{13} \mathrm{C}$ NMR (CD $\left.{ }_{3} \mathrm{OD}\right): 58.8,126.8,127.4,128.2,129.3,158.7,174.4$; HRMS: $\mathrm{C}_{9} \mathrm{H}_{18} \mathrm{~N}_{2} \mathrm{O}_{2}$ calculated $176.0586 \mathrm{amu}$, found $176.0583 \mathrm{amu}$.)

\section{(S)-3,5-Diphenylhydantoin (6)}

A solution of L-phenylglycine $(7.5 \mathrm{~g}, 0.05 \mathrm{~mol})$ was dissolved in water $(20 \mathrm{~mL})$ containing potassium hydroxide $(3.0 \mathrm{~g}, 0.05 \mathrm{~mol})$, after the solution was stirred for $10 \mathrm{~min}$, phenylisocyanate $(6.0 \mathrm{~g}, 0.05 \mathrm{~mol})$ was added and the mixture was warmed to $65 \infty \mathrm{C}$ for $5 \mathrm{~h}$. The solution was then cooled and left to sit for $2 \mathrm{~h}$ at which time the precipitated diphenylurea was filtered off and the filtrate was acidified with concentrated $\mathrm{HCl}(5 \mathrm{~mL})$ to precipitate the hydantoic acid. The hydantoic acid obtained was then cyclized by heating it at reflux for $1 \mathrm{~h}$ in $50 \mathrm{~mL}$ of water and $50 \mathrm{~mL}$ of concentrated $\mathrm{HCl}$. When the solution was cooled the product crystallized and was collected by filtration. It was then recrystallized using an ethanol and water (95:5) mixture. (Crystalline product $(9.84 \mathrm{~g}, 78 \%) ; \mathrm{mp}=157-159^{\circ} \mathrm{C}$ (lit. $\mathrm{mp}=158-160^{\circ} \mathrm{C}$ [8]); ${ }^{1} \mathrm{H}$ NMR ( $\left.\mathrm{CD}_{3} \mathrm{OD}\right): 4.14$ (s, 1H), 7.39-7.48 (m, 10H); 13C NMR (CD3OD): $57.4,126.6,127.4,127.6,127.9,128.3,128.4,129.1,129.7$, 159.3, 173.2; HRMS: $\mathrm{C}_{15} \mathrm{H}_{12} \mathrm{~N}_{2} \mathrm{O}_{2}$ calculated $252.0899 \mathrm{amu}$, found 252.0889 amu.) 